\title{
Rearview
}

\section{Vodafone signals the demise of copper}

\section{A regular column on the information industries}

\author{
Jason Whalley and Peter Curwen \\ Jason Whalley is Associate Professor \\ at the Newcastle Business School, \\ Northumbria University, Newcastle, \\ UK. \\ Peter Curwen is Visiting Professor of \\ Mobile Communications at Newcastle \\ Business School, Northumbria \\ University, Newcastle, UK.
}

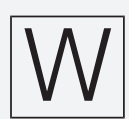

ith quad-play being the ultimate goal of major incumbents across the developed world, they have increasingly found themselves in competition with companies that approach this issue from the opposite dimension - that is, not as a mobile operator seeking to obtain fixed-wire connectivity but as a fixed-wire service provider seeking to obtain mobile connectivity. For example, the likes of Vodafone and Liberty Global have met head to head in a number of markets, especially Germany and the UK, but starting from quite different places.

Over the past couple of years, there have been considerable comments about the possibility of a merger between Vodafone and Liberty Global. There are clear benefits arising from such a merger, as it would combine Vodafone's mobile operations, largely in Europe, with Liberty Global's cable and content operations, creating a quad-play operator capable of challenging incumbent fixed-wire operators. Rumours about a possible merger between the two companies first appeared in mid-2015, though it soon became apparent that Vodafone and Liberty Global were not discussing a full merger but rather an asset swap.

It was suggested that Vodafone would sell its Dutch and British mobile operations to Liberty Global while acquiring Liberty Global's German cable business. Another suggestion was that Vodafone would acquire Liberty Global's Dutch and British cable operations, while selling its German mobile business to the US company.

However, in late September 2015, the two companies ended their talks, although it was not exactly clear why. It was suggested that Liberty Global's complex structure prevented assets being swapped, and that there would be severe regulatory challenges to be faced in Germany by any proposed swap. The strategic nature of the UK market for both companies was alluded to by some observers. 
While a full merger or asset swap was evidently off the table, the logic of combining fixed-wire with mobile operations to provide quad-play remained, so it was hardly a surprise when the two companies announced that they would merge their Dutch businesses to create a 50:50 joint venture branded as VodafoneZiggo. The deal was announced in February 2016 and completed in December. Despite this, rumours of an asset swap resurfaced in March 2017. This time, however, the focus was on the UK where Vodafone was arguably on the back foot. Not only was its mobile business struggling to keep up with its two main rivals but its unsatisfactory customer service was also attracting a lot of negative publicity and regulatory attention and it had been late to enter the fixed-wire broadband market. It was alleged that Vodafone would sell its UK operations to Liberty Global, thereby creating a quad-play operator better able to compete against rivals such as BT and Sky. These talks, if true, also appear to have ended in failure.

This left Vodafone with a dilemma as to how it could now enhance the competitiveness of its UK operations. As Virgin Media is effectively the only cable operator in the UK, the strategy adopted in Germany and Spain, where, respectively, Vodafone acquired Kabel Deutschland in 2013 and ONO in 2014, was not viable. The first hint of a possible way forward emanated from Germany, where, in September 2017, Vodafone announced that it would roll out a new fibre-optic network linking 2,000 business parks at an alleged cost of $€ 1$.6bn. The chosen partner for this is Deutsche Glasfaser. In addition, up to $€ 400 \mathrm{~m}$ has been set aside to expand Vodafone's existing network to a million homes in rural areas and a further $€ 200 \mathrm{~m}$ is to be spent on upgrading cable infrastructure serving its 12.6 million customers.
This investment is Vodafone's largest since "Project Spring" which upgraded the company's mobile infrastructure across Europe, and was described as being "transformational" by the CEO of Vodafone Germany. Some observers noted that it threw down the gauntlet to Liberty Global given that Vodafone owns Germany's largest cable operator, while Liberty Global owns the second largest. The investment would expand and improve Vodafone's infrastructure in Germany, and thus, enhance its competitiveness in the market, but without moving it into direct competition with Liberty Global. It was suggested by some observers that the investment could encourage Liberty Global to return to the negotiating table.

Although the total cost for Vodafone appears to be rather high, analysts tend to the view that the risk is low and the rate of return is potentially very positive. In this regard, it is significant that Vodafone's German operations generated around 30 per cent of the company's entire European revenues in the quarter ending 30 June 2017. The revenue generated in Germany is substantially larger than that generated in any other European market, so investment is as much about defending its position in a core market as it is about enhancing its competitiveness.

At around the same time that Vodafone was announcing its infrastructure investment in Germany, it emerged that it was also considering investing in the UK. There was, however, a caveat they wanted a partner with which to share the costs of this investment. Just a few months later, in November 2017, Vodafone announced that it would join with CityFibre to deliver 1 GB (gigabyte) connections by rolling out fibre to one million properties. Initially they would invest a combined £500m, with the joint venture taking up to four years to connect the one million properties in 12 of the cities and towns already covered by CityFibre. A second phase, for which no capital investment figure was mentioned, would see another four million properties connected by 2025.

Vodafone benefits from this deal in two ways. First, it gains access to a fibre network that it can bundle with its existing services to enhance its competitiveness in the UK. Second, the deal highlights that alternatives to Openreach do exist. Vodafone has been a vocal critic of the regulator Ofcom, arguing that Openreach is failing to make available to the likes of Vodafone the means to deliver their ownbrand fibre services. Quite simply, using the copper-based network offered by Openreach limits Vodafone's ability to differentiate itself from many of its rivals, as they are also using the same (inadequate) wholesale products.

These two investments in Germany and the UK need to be seen as part of the wider move towards a gigabyte society that is being encouraged by the European Union, where improved connectivity will give rise to a whole series of new products and services and thereby boost the European economy. What is surprising is how far the scale of investment differs between the two markets. Germany may be Vodafone's largest European market, but the UK is its second largest; yet, considerably more is being invested by Vodafone in Germany than in the UK - it is investing €2bn in Germany, but only $£ 500 m$ in partnership with CityFibre in the UK. Of course, Vodafone has made other investments in the UK in the past, but the distinct impression is given that Germany is of greater strategic importance than its home market.

The investments indicate that Vodafone recognises the limitations 
associated with copper. Copper may be ubiquitous, but it is not capable of very high-speed data transfer and fibre is widely recognised as a "future proof" technology. By investing in fibre, Vodafone is laying the foundations for its future prosperity but incorporating fibre into how it competes is going to be challenging. In the UK, this will take several years to accomplish, and it is only with the second phase of the investment that Vodafone will gain a geographically widespread fibrebased presence. And even when it does, the deal with CityFibre will provide Vodafone with just five million connections, while Virgin Media's "Project Lightning" will expand its footprint to 17 million homes and businesses. Moreover, because of providing only five million fibre connections, the products provided by Openreach will not only remain important but also limit what Vodafone can do.

Arguably, more challenging is what to do with the fibre connections that these investments provide. In the UK, both Sky and BT compete on content, while Virgin Media emphasises the speed of its broadband connections. While investing in fibre will allow Vodafone to compete against Virgin Media on speed, it is not clear how it will compete against BT or Sky. It could join its quad-play rivals and invest in content, but such a strategy will be costly, especially if Vodafone seeks to obtain football rights.

Alternatively, if Vodafone does not acquire unique content then it could seek to compete on price, but this is something that it already appears to be doing with its existing broadband products. This leaves Vodafone with a dilemma: how to make the best use of its fibre investments and compete against its quad-play rivals without engaging in a price war? In other words, Vodafone may have signalled that the future is fibrebased, but it does not yet know what form this future will take.

\section{About the authors}

Jason Whalley is Associate Professor of Digital Economy at the Newcastle Business School, Northumbria University and Aliate Professor at TELECOM École de Management, Institut Mines \& Telecoms, Évry, France.

Peter Curwen is Visiting Professor of Mobile Communications at the Newcastle Business School, Northumbria University. Peter Curwen is the corresponding author and can be contacted at: pjcurwen@hotmail.com 